\begin{tabular}{l||l} 
Sor: $10.1515 /$ eec-2017-0014 & $\begin{array}{l}\text { astern } \\
\text { Eropean } \\
\text { Countryside }\end{array}$ \\
\hline $23^{\prime} 2017$
\end{tabular}

\title{
In Memoriam of \\ Professor Zbigniew Tadeusz Wierzbicki (1919-2017)
}

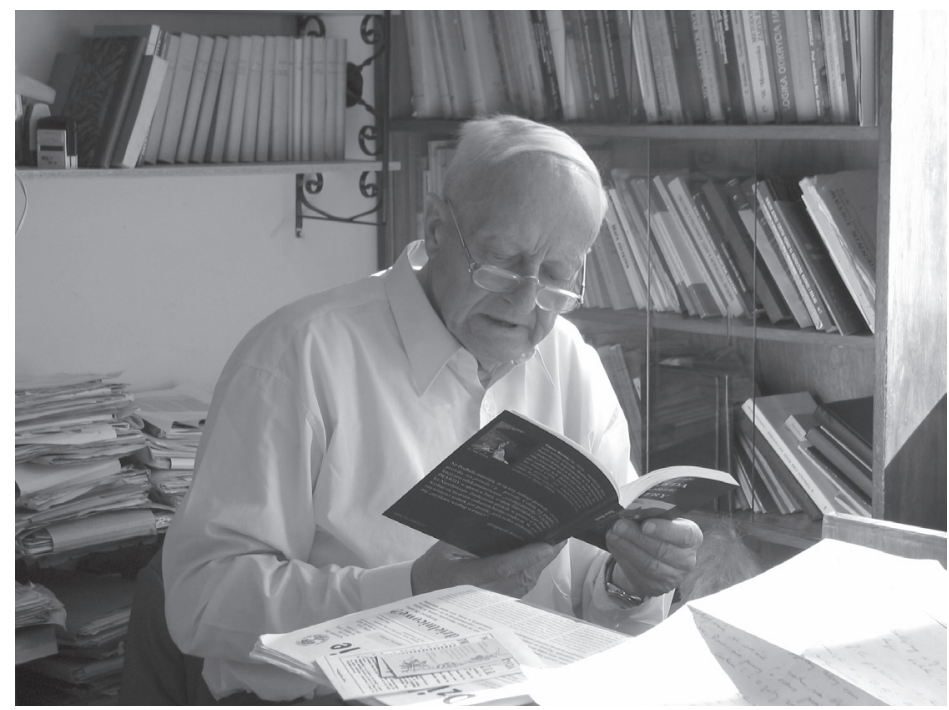

Professor Zbigniew Tadeusz Wierzbicki's long life that came to an end on 7 June 2017 was a balanced and these days rare blend of personal virtues of an outstandingly righteous and noble man, his recognised and practically verified research activity, and his unselfish organic work for the society, the nation, and the Polish state.

Professor Wierzbicki was a retired UMK professor who worked in the Institute of Sociology of the Nicolaus Copernicus University (UMK) in Torun between 1982 and 1994 and previously in the Institute of Philosophy and 
Sociology of the Polish Academy of Sciences. He was brought up in a family with rich patriotic and public-spirited traditions (his father was an officer in the First Brigade of the Polish Legions, a volunteer-medic, while his mother came from the family of Wacława Peretiatkowicz, the founder of a famous school for girls in Kiev.) His personality was strongly influenced by a junior high school in Rydzyna run by Tadeusz Łopuszański. At home as well as at school he learnt a positivist ethic of work at the grassroots level.

A leading Polish rural sociologist, who continued traditions of rural science that were begun in Poland by Władysław Grabski and Franciszek Bujak (among others he authored some works devoted to the Żmiąca village that refereed to F. Bujak's monograph from 1903. "Żmiąca. Wieś powiatu limanowskiego. Stosunki gospodarcze i społeczne" [Żmiąca. A village in the Limanowa District. Economic and social relations.]). His academic work was appreciated globally - he was invited to lecture at the universities in France and the United States. As a man of science, he was always guided by the principle of action and research, bringing together practical activities and academic work in three areas: (1) activation of local communities, (2) tackling alcoholism, (3) environmental protection.

At the end of the 1960s and at the beginning of the 1970s, as a sociologist he developed (jointly with Alvin L. Bertrand, an American sociologist) the theoretical basis for activation and development of local communities and social environmental science (created in the 1990s). They form the basis of a fundamental paradigm of rural development operating under the name of revitalisation of rural areas that was developed in Poland by his students from Torun. Its principles provided the foundations for the programme of local communities' development that is being implemented nowadays in social practice in many European countries under the name of "Rural areas renewal".

In 1992-2005, he supported the Eastern European Countryside as a member of its Advisory Council.

He was a prominent public-spirited activist. He began his social activities already at a very early age. In autumn 1939 , when he was only 20 , together with his mother he organised secret courses at the secondary school level. In the period from 1 October 1939 to 30 September 1941, the school operated 
underground. With the connivance of a district school inspector from Puławy the school broke cover and until 1944 it was run as a secondary School of Trade. He lectured there on cooperatives and, unofficially, on Poland's history. Additionally he looked after an illegally operating school's scout group.

In 1946-1947, he worked in Wrocław's branch of Polski Związek Zachodni [Polish Western Union], where he engaged in defending indigenous people persecuted by looters who took advantage of impunity resulting from the support they received from a corrupted local administration and officers of the secret political police. Fearing for his life, professor Wierzbicki left Wrocław.

His social sensitivity demonstrates itself in his commitment to the environmental protection movement. He was a leading activist of the green movement in Poland. He was awarded the title of "The Patron of Nature" by the Stowarzyszenie Pracownia na rzecz Wszystkich Istot [Workshop for All Living Creatures Association]. He was also awarded and honoured by The Nature Preservation League and Polski Klub Ekologiczny [Polish Eco Club], and he was summoned to testify as an expert in social aspects of environmental protection by public administration and other bodies. Alongside his academic activity in sociology of environmental protection, he also promoted knowledge about the environment. In 1993, he became a member of Environmental Protection Committee affiliated with the President of Poland's office, he was a member of the Academic Board of the Board of Directors at The Nature Preservation League (in 1977-1982, he served as its vice-chairman).

Since 2001, he had funded and published a bimonthly periodical called "Bunt Młodych Duchem" [A rebellion of the young at heart] which he also edited. The periodical raised political, historical, and environmental issues as well as those related to outlook on the world and current affairs, especially in Poland, presenting them in the spirit of respecting human rights, social dialogue, particularly with neighbouring nations, dialogue between religions, and improving selfgovernance and environmental protection.

Selected works:

- Agribusiness - wyłaniająca się nowa gałąź amerykańskiej socjologii wsi [Agribusiness - a new emerging branch of American rural sociology] (1968)

- Badaniaamerykańskienadaktywizacjąspołecznościlokalnej[American research into activation of local communities] (1969) 
- Socjologia wsi w Stanach Zjednoczonych: stan $i$ tendencje rozwojowe [Rural sociology in the United States: current state and development tendencies for the future] (1970, jointly with Alvin L. Bertrand)

- Ewolucja rolniczych spółdzielni produkcyjnych w uprzemysłowionym regionie [Evolution of agricultural cooperatives in industrialised regions] (1970)

- Ochrona środowiska naturalnego wsi [Protecting the natural environment in rural areas] (1973)

- Gaeki - zespołowe gospodarstwa rolne we Francji [GAECs - collective agricultural enterprises in France] (1975)

- Ochrona krajobrazu w socjoekologicznej perspektywie [Landscape protection in social and enviromental perspective] (1980)

- Ekologia człowieka a sozoekologia społeczna [The ecology of human being and social environmental science] (1982)

- Aktywizacjairozwójspołecznościlokalnychiśrodowiskowych[Activation and development of local and enviromental communities] (1987)

- Socjologia wsi we Francji [Rural sociology in France] (1994, jointly with Placide Rambaud)

- Dimitrie Gusti: socjolog niepodległej Rumunii [Dimitrie Gusti: A sociologist of the independent Romania] (1999)

- Sozoekologiaspołeczna:główneproblemy, materiały, rozwiązania[Social aspects of environmental science: main issues, documents, solutions] (2008) 